\title{
Morphometric Analysis of Tubercles at the Anterior Margin of Foramen Magnum
}

\author{
A.Sai Sanjith ${ }^{1}$, and Yuvaraj Babu K ${ }^{2}$ \\ ${ }^{1}$ Saveetha Dental college and Hospitals, Saveetha Institute of Medical and \\ Technical Sciences, Saveetha University, Chennai - 600077, India \\ ${ }^{2}$ Assistant Professor, Department of Anatomy, Saveetha Dental college and Hospitals, Saveetha \\ Institute of Medical and Technical Sciences, Saveetha University, Chennai - 600077, India
}

\section{ABSTRACT}

The basilar part Occipital bone is formed by the initial three primitive vertebrae (or occiput blasts), the most caudal of which is alleged occipital vertebra. The peculiarity prompts anomalous bone arrangement in the region of the anterior edge of foramen magnum, either in the midline or potentially along the side. This peculiarity is known as the third condyle, remnants of occipital vertebra and is ossified with the odontoid bone.The aim of this study is to analyse the morphology of tubercles present at the anterior margin of foramen magnum. 72 south Indian adult unsexed human skulls were analyzed for the appearance of precondylar tubercles from the Department of Anatomy, Saveetha Dental College et Hospitals.The distance from both mastoid process, external occipital protuberance are measured by using vernier calliper. Out of these 72 skulls, 3 skulls showed unilateral midline tubercles. In this study, The occurrence of tubercle at the anterior margin of the foramen magnum is $4.16 \%$.

\section{KEY WORDS: FORAMEN MAGNUM ANOMALIES, TUBERCLE IN ANTERIOR MARGIN, OCCIPITAL VERTEBRAE.}

\section{INTRODUCTION}

The skull has a pinnacle importance in the vertebral column.The foramen magnum is the huge opening in the occipital bone, and transmits significant neurovascular structures (Standring et al., 2005). Anomalies found around the foramen magnum may be of clinical significance as is closely related to vascular and nervous structures. Position of this tubercle may be related to traumatic medullary lesions of the occipito-vertebral region.

\section{ARTICLE INFORMATION}

${ }^{*}$ Corresponding Author: yuvarajbabu@saveetha.com Received 27th July 2020 Accepted after revision 28th Sep 2020 Print ISSN: 0974-6455 Online ISSN: 2321-4007 CODEN: BBRCBA

Thomson Reuters ISI Web of Science Clarivate Analytics USA and Crossref Indexed Journal

\section{Clarivate
Analytics}

NAAS Journal Score 2020 (4.31) SJIF: 2020 (7.728)

A Society of Science and Nature Publication,

Bhopal India 2020. All rights reserved.

Online Contents Available at: http//www.bbrc.in/

Doi: http://dx.doi.org/10.21786/bbrc/13.8/121
The tubercles within the foramen are significant as they could interfere with the sensitive structure that goes back and forth from the skull. It is very significant in the field of neurology that such structures may intervene in the development at the atlanto-occipital joint (Ahmed et al., 2015). It is additionally significant within the field of neurology that such structures may impede at the atlantooccipital joint (Prakash et al., 2011). Previously our department has published extensive research on various aspects of dentistry (Begum et al, 2017; Ganapathy, Kannan and Venugopalan, 2017; Jain, 2017a, 2017b; Ranganathan, Ganapathy and Jain, 2017; Ariga et al., 2018; Gupta, Ariga and Deogade, 2018; Anbu et al., 2019; Ashok and Ganapathy, 2019; Duraisamy et al., 2019; Varghese, Ramesh and Veeraiyan, 2019), this vast research experience has inspired us to research about morphometric analysis on the tubercles at the anterior margin of the foramen magnum.

\section{MATERIAL AND METHODS}

72 unsexed South Indian adult human skulls from the Anatomy Department of Saveetha Dental College were

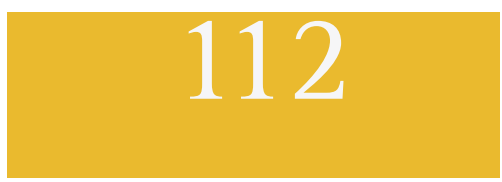


examined for the presence of tubercle in the anterior margin of Foramen magnum.The skulls with tubercles at foramen magnum were examined further, parameters of the tubercles are measured. The distance from mastoid process, external occipital protuberance were measured using vernier callipers.

\section{RESULTS AND DISCUSSION}

From the research we found that 3 out of 72 skulls had tubercle at the anterior margin of the foramen magnum. The occurrence of tubercle at the anterior margin of the foramen magnum is $4.16 \%$. The failure of distal occipitoblasts to intertwine with other bones creates an unusual bony appearance on the outer surface of skull around foramen magnum, an anomaly called as "appearance of occipital vertebra"(Lombardi, 1961). Failure in Hypochondrial ossification during development may show a rigid arrangement in that region, called tubercle (Fig.1)(Vasudeva and Choudhry, 1996).

Table 1. The table shows the length of the tubercle from the landmarks in the skull(mastoid process, external occipital protuberance).

\begin{tabular}{|l|c|c|c|}
\hline $\begin{array}{l}\text { Distance from } \\
\text { Anatomical } \\
\text { landmarks }\end{array}$ & $\begin{array}{c}\text { Right } \\
\text { Mastoid } \\
\text { Process }\end{array}$ & $\begin{array}{c}\text { Left } \\
\text { Mastoid } \\
\text { Process }\end{array}$ & $\begin{array}{c}\text { External } \\
\text { Occipital } \\
\text { Protuberance }\end{array}$ \\
\hline SKULL 1 & $4.57 \mathrm{~cm}$ & $4.36 \mathrm{~cm}$ & $6.62 \mathrm{~cm}$ \\
\hline SKULL 2 & $5.48 \mathrm{~cm}$ & $5.47 \mathrm{~cm}$ & $6.55 \mathrm{~cm}$ \\
\hline SKULL 3 & $4.86 \mathrm{~cm}$ & $4.57 \mathrm{~cm}$ & $7.56 \mathrm{~cm}$ \\
\hline
\end{tabular}

Figure 1: Shows the tubercle at the anterior margin of the foramen magnum

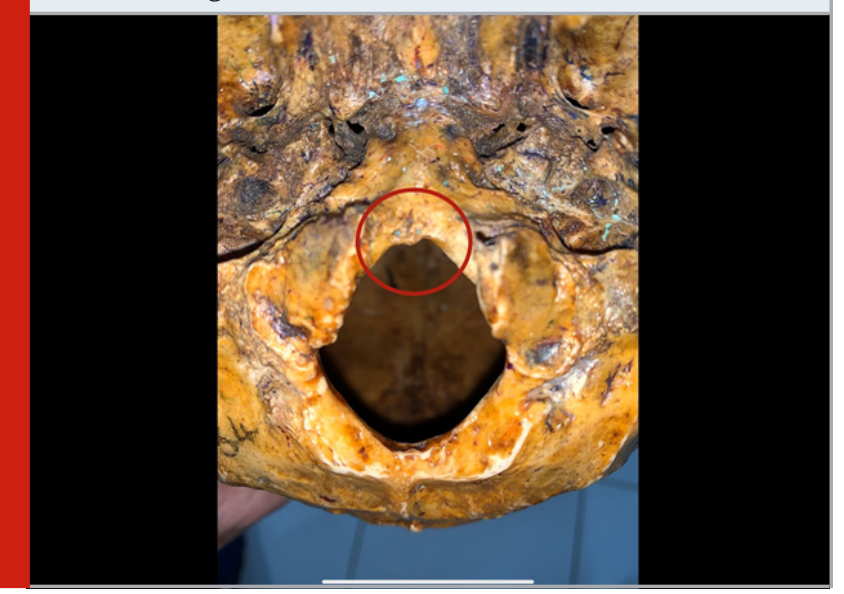

Besides being of anthropological and ethnological importance, these variations might be significant in a clinical setting. Protruding vertebral components along the anterior edge of foramen magnum intervened between the basiocciput and the atlas may decrease the periphery of the foramen or cause asymmetry (Nicholson and Sherk, 1968; Vinken and Bruyn, 1968). Extended middle or paramedian tubercle's ventral to the foramen may shape a pseudojoint with the apical section of the odontoid process, in this way influencing the important tracts passing through the atlanto-occipital articulation(Cagle, 1989).

Romanes and Basmajian in their research said that tubercles at the anterior margin can intervene in the important structures passing through the foramen magnum, A similar explanation is portrayed by Bergman et al (Bergman, Afifi and Miyauchi, 2018). In the research done by Naderi et.al, its occurrence has been accounted for to be $0.8 \%$ (Naderi et al., 2005). The frequency of tubercles at foramen magnum has been reported as 0.5$0.8 \%$ in the research done by Prakash B.S (Prakash et al., 2011). Lakhatia et.al has done a research in which, out of 422 skulls that were examined , 22 skulls the projection took the form of a tubercle measures 0.5$1.5 \mathrm{~mm}$ in length, whereas in 32 skulls the tubercle is $2-2.5 \mathrm{~mm}, 2$ skulls were $4 \mathrm{~mm}$. Tubercle was present in $15 \%$ of skulls examined (Lakhtakia et al., 1991). Out of 66 skulls studied 1.5\% are with the tubercle in the research done by Blaszczyk et.al, all the skulls were mostly of Russian population (Błaszczyk, Kaszuba and Kochanowski, 1980).

In the research done by Lombardi et.al, the incidence of tubercles was of $0.28 \%$ mainly of the western world population (Lombardi, 1961). In the research done by Harrower et.al, 382 skulls have been studied, 1.3\% incidence was found, It was from the population of South American people (Harrower, 1923). In the research done by Vasudeva et.al, Out of 265 skulls, 37 skulls showed tubercles at the anterior margin, 2\% occurrence was found, it is from the northern part of India (Vasudeva and Choudhry, 1996). In the research done by Trotter et.al, Pre condylar and anterior marginal tubercles are formed in 2\% of skulls of Negros, This research was done on skulls of South African population (Trotter, Broman and Peterson, 1960). In the research done by Vanquest et.al, 38 skulls out of 450 skulls showed the presence tubercle, which is $0.85 \%$ of incidence, it was mainly of European population (Pastor Vázquez, Gil Verona and García Porrero, 1999). Surendra et.al research concluded that " presence of tubercle at the anterior margin is not a normal incidence and is not found in all people" (AlMotabagani and Surendra, 2006).

In the research done by P.K.Lakhatia (Lakhtakia et al., 1991) the percentage of tubercles found to be $15 \%$ which is higher than our study of $4.6 \%$ occurrence. In the researches done by Ahmed (Ahmed et al., 2015), Blaszczyk et.al (Błaszczyk, Kaszuba and Kochanowski, 1980), Haritha (Harrita and Santhanam, 2019), Broman. GE (Trotter, Broman and Peterson, 1960), Surendra (Al-Motabagani and Surendra, 2006) the percentage of tubercles found was less than the occurrence in our study. Limitations of the study are less number of skulls and restriction of sample to specific local region. Future extension lies in the field of orthopedics and neurology as such peculiarities may cause pressure of the neural structures and furthermore research may be needed. 


\section{CONCLUSION}

Anatomically, the location of an insignificant precondylar tubercle may create neurological signs of pressure since it is situated outside the periphery of foramen magnum. Our report of incidence of $4.6 \%$ of tubercle in the anterior margin of foramen magnum would help neurologists and surgeons about anomalies in the region around foramen magnum.

\section{ACKNOWLEDGEMENTS}

We acknowledge Department of Anatomy for allowing us to use bones from their collection for this study

Conflict of Interest: The author declares that there is no conflict of interest in the present study.

\section{REFERENCES}

Ahmed, K. et al. (2015) 'A study on tubercles at the anterior margin of the foramen magnum', Journal of Evolution of Medical and Dental Sciences, 4, p. 54+. Al-Motabagani, M. A. and Surendra, M. (2006) 'Total occipitalization of the atlas', Anatomical science international, 81(3), pp. 173-180.

Anbu, R. T. et al. (2019) 'Comparison of the Efficacy of Three Different Bone Regeneration Materials: An Animal Study', European journal of dentistry, 13(1), pp. 22-28.

Ariga, P. et al. (2018) 'Determination of Correlation of Width of Maxillary Anterior Teeth using Extraoral and Intraoral Factors in Indian Population: A Systematic Review', World Journal of Dentistry, 9(1), pp. 68-75.

Ashok, V. and Ganapathy, D. (2019) 'A geometrical method to classify face forms', Journal of oral biology and craniofacial research, 9(3), pp. 232-235.

Begum R, Ariga P, Ashish Jain 'Evaluation of Corrosive Behavior of Four Nickel-chromium Alloys in Artificial Saliva by Cyclic Polarization Test:An in vitro Study' (2017) World Journal of Dentistry, 8(6), pp. 477-482.

Bergman, A. R., Afifi, A. K. and Miyauchi, R. (2018) 'Illustrated encyclopedia of human anatomic variation: opus I: muscular system: alphabetical listing of muscles: F: flexor hallucis longus', URL: http://www. anatomyatlases. org/AnatomicVariants/ MuscularSystem/Text/F/22Flexor. shtml [accessed July 2011].

Błaszczyk, B., Kaszuba, A. and Kochanowski, J. (1980) 'Atypical foramina of the base of the skull', Folia morphologica, 39(2), pp. 201-209.

Cagle, S. K. (1989) 'Book Review: The Craniovertebral Junction and Its Abnormalities by John C. VanGilder, Arnold H. Menezes, and Kenneth D. Dolan. Published in 1987 by Futura Publishing Company, Mount Kisco, New York, 251 pages, $\$ 65.00$, Journal of Child Neurology, pp. 75-75. doi: 10.1177/088307388900400119.

Duraisamy, R. et al. (2019) 'Compatibility of Nonoriginal Abutments With Implants: Evaluation of Microgap at the Implant-Abutment Interface, With Original and Nonoriginal Abutments', Implant dentistry, 28(3), pp. 289-295.

Ganapathy, D. M., Kannan, A. and Venugopalan, S. (2017) 'Effect of Coated Surfaces influencing Screw Loosening in Implants: A Systematic Review and Meta-analysis', World Journal of Dentistry, 8(6), pp. 496-502.

Gupta, P., Ariga, P. and Deogade, S. C. (2018) 'Effect of Monopoly-coating Agent on the Surface Roughness of a Tissue Conditioner Subjected to Cleansing and Disinfection: A Contact Profilometric Study', Contemporary clinical dentistry, 9(Suppl 1), pp. S122S126.

Harrita, S. and Santhanam, A. (2019) 'Determination of Physical Height Using Clinical Crown Height of Deciduous Teeth', Indian Journal of Forensic Medicine and Toxicology. indianjournals.com. Available at: http://www.indianjournals.com/ijor.aspx?target=ijor:i jfmt Ctvolume $=13$ tissue $=4$ tarticle $=005$.

Harrower, G. (1923) 'Variations in the Region of the Foramen Magnum', Journal of anatomy, 57(Pt 2), pp. 178-192.

Jain, A. R. (2017a) 'Clinical and Functional Outcomes of Implant Prostheses in Fibula Free Flaps', World Journal of Dentistry, 8(3), pp. 171-176.

Jain, A. R. (2017b) 'Prevalence of Partial Edentulousness and Treatment needs in Rural Population of South India', World Journal of Dentistry, 8(3), pp. 213-217. Lakhtakia, P. K. et al. (1991) 'A tubercle at the anterior margin of the foramen magnum', Journal of anatomy, 177, pp. 209-210.

Lombardi, G. (1961) 'The occipital vertebra', The American journal of roentgenology, radium therapy, and nuclear medicine, 86, pp. 260-269.

Naderi, S. et al. (2005) 'Morphometric analysis of human occipital condyle', Clinical neurology and neurosurgery, 107(3), pp. 191-199.

Nicholson, J. T. and Sherk, H. H. (1968) 'Anomalies of the occipitocervical articulation', The Journal of bone and joint surgery. American volume, 50(2), pp. 295-304.

Pastor Vázquez, J. F., Gil Verona, J. A. and García Porrero, M. (1999) 'Carotid canal dehiscence in the human skull', Neuroradiology. Springer, 41(6), pp. 447-449.

Prakash, B. S. et al. (2011) 'A tubercle at the anterior margin of foramen magnum', Int J Anat Var, 4, pp. 118-119.

Ranganathan, H., Ganapathy, D. M. and Jain, A. R. (2017) 'Cervical and Incisal Marginal Discrepancy 
in Ceramic Laminate Veneering Materials: A SEM Analysis', Contemporary clinical dentistry, 8(2), pp. 272-278.

Standring, S. et al. (2005) 'Gray's anatomy: the anatomical basis of clinical practice', AJNR. American journal of neuroradiology. Am Soc Neuroradiology, 26(10), p. 2703.

Trotter, M., Broman, G. E. and Peterson, R. R. (1960) 'Densities of Bones of White and Negro Skeletons', JBJS, 42(1), p. 50.
Varghese, S. S., Ramesh, A. and Veeraiyan, D. N. (2019) 'Blended Module-Based Teaching in Biostatistics and Research Methodology: A Retrospective Study with Postgraduate Dental Students', Journal of dental education, 83(4), pp. 445-450.

Vasudeva, N. and Choudhry, R. (1996) 'Precondylar tubercles on the basiocciput of adult human skulls', Journal of anatomy, 188 ( Pt 1), pp. 207-210.

Vinken, P. J. and Bruyn, G. W. (1968) 'Handbook of clinical neurology. Vol. 6', Headache. 